\title{
Agroecological Substantiation for the Use of Treated Wastewater for Irrigation of Agricultural Land
}

\author{
Sergey Vasilyev ${ }^{1}$, Yulia Domashenko ${ }^{1 *}$ \\ 1 Russian Research Institute of Land Improvement Problems, 190, Baklanovskiy Ave., 346421, Novocherkassk, \\ Russian Federation \\ * Corresponding author's e-mail: domachenko_u@list.ru
}

\begin{abstract}
The objective of this work is the agroecological substantiation of the use of treated wastewater for irrigation of agricultural land. As the result of the experimental research, it was established that the soil microflora plays an essential role in strengthening or weakening the biological activity of soil. Therefore, with an irrigation rate of $250 \mathrm{~m}^{3} /$ ha of wastewater, a 1.5 times increase in the number of microbiota colonies is observed on average both in hog farms and cattle breeding complexes; with a rate of $350 \mathrm{~m}^{3} / \mathrm{ha}$ - a 2-fold increase; with a rate of $450 \mathrm{~m}^{3} / \mathrm{ha}-\mathrm{a}$ 3.5-4-fold increase. An increase in nitrifying soil features has also been observed. Thus, if the value on the control in the soil layer from $0 \mathrm{~cm}$ to $60 \mathrm{~cm}$ is $27.2 \mathrm{mg}$ of nitrate per $1 \mathrm{~kg}$ of arid soil, in the version with wastewater irrigation it reaches $46.7 \mathrm{mg}$. According to the research results, the use of defecate, the waste of sugar production, in the treatment of wastewater of livestock farms does not have a negative agroecological impact on the soil. Therefore, the method of wastewater treatment of pig-breeding complexes and farms can be recommended for use in irrigation reclamation, which includes treatment of wastewater with burnt defecate in the dose of 50-200 mg/ $\mathrm{dm}^{3}$, with the $\mathrm{pH}$ value varying in the range of 7.5-8.5. After settling-out of the obtained mixture in settlers, it is divided into a transparent liquid fraction and the sediment, i.e. an organomineral fertilizer. Afterwards, the fluid body is fed to irrigation of agricultural land, and its excess is discharged into waterways and reservoirs. The sediment is fed to the vortex layer equipment with mobile ferromagnetic particles or thermolized, where their complete disinfection takes place.
\end{abstract}

Keywords: water resources, microorganisms, wastewater, development method, irrigation, soils.

\section{INTRODUCTION}

According to the UN Agenda for the Third Millennium, water will play a decisive role. If the deficit of fresh water, including the water for agricultural and industrial needs, was estimated at 230 billion $\mathrm{m}^{3} /$ year in 2000 , then by 2025 this deficit on the planet will increase to 1.3-2.0 trillion $\mathrm{m}^{3} /$ year.

According to the State Water Registry, the total drawing of water from the natural water bodies in the Russian Federation in 2015 was $68.6 \mathrm{~km}^{3}$ (in $2014-70.8 \mathrm{~km}^{3}$ ). At the same time, in 2015 , the amount of polluted wastewater discharged into the country's water bodies decreased to 14.4 billion $\mathrm{m}^{3}$, which is $2.4 \%$ less than in 2014 . The share of polluted runoffs in the total volume of wastewater disposal in water bodies in 2010, 2014 and 2015 remained at the level of almost $34 \%$. The existing dynamics can be explained by the introduction of circulating water systems and the use of wastewater for agriculture, especially in the irrigation of agricultural land [State report, 2016; Shchedrin, Vasiliev, 2011].

The experience of foreign countries (USA, Australia, etc.) shows that the secondary use of treated wastewater for irrigation reduces the discharge of wastewater and the consumption of fresh water from water sources. In addition, the use of treated wastewater for irrigation of agricultural land contributes to the formation of agriculture, significant yield and profitability of cultivation of agricultural crops [Glotov, 1987]. 
However, the wastewater of agro-enterprises is diverse in chemical composition; hence, it is necessary to take into account not only its convenient properties, but also its influence on agroecological soil criterion [Feigin, Ravina, Shalhevet, 1991; Gostishchev, 1994]. Special attention should be given to the influence of organic substances in the composition of wastewater and their decay products on the ecological ecosystem of soils [Feigin, Ravina, Shalhevet, 1991; Gostishchev, 1994].

The research object is the agroecological substantiation for the use of treated wastewater for irrigation of agricultural land.

Scientific novelty of the research is to assess the effect of treated wastewater on the ecological state of soils processed by the waste of sugar beet production - defecate.

The main tasks of the conducted research were:

- Complex agroecological assessment of the effect of treated wastewater on soil biota and nitrifying soil features;

- Substantiation of the use of methods for preparing wastewater from livestock farms by the waste of sugar production - defecate.

\section{MATERIALS AND METHODS}

The object of the research was the soil, which had been processed with treated wastewater from livestock farms.

The soil cover of the experimental plots is represented by the southern chernozem. The samples were taken from the $40 \mathrm{~cm}$ top part of soil cover. Chernozems in the southern surveyed area in the $0-40 \mathrm{~cm}$ layer are not saline and are not subjected to alkalinization processes.

The granulometric composition of the soils on the test site is homogeneous and is represented mainly by heavy loam. The structural state of dry sieving is excellent, the water resistance of aggregates throughout the site is good. On average, the bulk density in the $0-20 \mathrm{~cm}$ layer of soil is $1.19 \mathrm{t} /$ $\mathrm{m}^{3}$, which corresponds to compacted arable land.

On average, the smallest moisture capacity for the $0-60 \mathrm{~cm}$ layer is $29.1 \%$, and for the $0-100$ cm layer $-27.6 \%$. Southern chernozems can have good moisture reserves in $0-0.2 \mathrm{~m}$ and very good in 0-1.0 m layers as well.

The presence of humus in southern chernozems in the surveyed section is low on average in the area, closer to the medium. According to the high humus content of the soil, they refer to weakly humified soils. The supply of nitrogen with nitrate is medium, whereas mobile phosphorus and exchangeable potassium - high.

The experiment was carried out from October to April 2015-2016. The sample was taken at a site for growing forage crops, the air temperature did not exceed $+5^{\circ} \mathrm{C}$. Due to low temperatures, the metabolism of microorganisms is slowed down, so the authors conducted further studies under laboratory conditions with a constant air temperature of $+25^{\circ} \mathrm{C}$. The investigated soil was distributed uniformly in a $30 \mathrm{~cm}$ layer in boxes measuring $40 \times 50 \mathrm{~cm}$.

Saprotrophic groups of microorganisms azotobacter, microfungus, actinomycetes - were chosen as test objects. Microorganisms (including actinomycetes) capable of using mineral forms of nitrogen are more often detected on starch-ammonia agar (SAA), containing (in grams per liter of distilled water): starch (soluble) - 10; $\left(\mathrm{NH}_{4}\right)_{2} \mathrm{SO}_{4}$ - 2; $\mathrm{K}_{2} \mathrm{HPO}_{4}-1 ; \mathrm{MgSO}_{4}-1, \mathrm{NaCl}-1 ; \mathrm{CaCO}_{3}$ -3 ; agar -20 .

When preparing Czapek's medium for fungi in an environment prepared for the detection of actinomycetes, the dibasic potassium phosphate is replaced with an equivalent amount of monobasic potassium phosphate.

Czapek's medium has the following composition (in grams per 1 liter of distilled water): sucrose or glucose $-20.0 ; \mathrm{NaNO}_{3}-2.0 ; \mathrm{K}_{2} \mathrm{HPO}_{4}$ - 1.0; $\mathrm{MgSO}_{4}-0.5 ; \mathrm{KCl}-0.5 ; \mathrm{CaCO}_{3}-3.0$; agar -20.0 .

Before Czapek's medium is added to Petri dishes, $4 \mathrm{ml}$ (per liter) of sterile concentrated lactic acid is introduced to the melted agar of this medium.

After incubation, the grown up colonies are counted and recalculation is carried out for $1 \mathrm{~g}$ of absolutely arid soil [Tepper, Shilnikova, Pereverzeva, 1979].

\section{RESULTS AND DISCUSSION}

Studies conducted by a number of authors have shown that treated wastewater may contain toxic-chemical elements in its composition that have a negative impact on the environment and health. On the basis of these researches, conducted in the irrigated area in the north of Tunisia, it was figured out that when the soil is irrigated with wastewater, the eclectic conductivity (EC) 
and the content of sodium $(\mathrm{Na})$, potassium $(\mathrm{K})$, calcium $(\mathrm{Ca})$, magnesium $(\mathrm{Mg})$, chlorine $(\mathrm{Cl})$, SAR, copper $(\mathrm{Cu})$, cadmium $(\mathrm{Cd})$ and nickel $(\mathrm{Ni})$ increased significantly and also had no prominent effect of $\mathrm{pH}$ on soil, zinc ( $\mathrm{Zn})$, cobalt (Co) and lead $(\mathrm{Pb})$. In this case, the growth in individual components significantly increased down the soil profile [Khaskhoussy et al., 2015].

The issue of water deficit in arid and semi-arid areas in the west of USA is also being addressed through the use of treated wastewater. Specifically, it is widely implemented in watering of golf fields and the city cultivated land. The studies on the assessment of the effect of the treated wastewater on environmental indicators of soils have shown that the soils which were irrigated with the treated wastewater are characterized by an increased amount of sodium (Na) 89-95\%; boron (B) - from 28 to $50 \%$ and phosphorus $(\mathrm{P})$ in the top soil [Qian, Mecham, 2005].

Oskar A. Palacios conducted the research on the effects of raw wastewater on the development of pathogenic flora in Chihuahua, Mexico. On the basis of the results of their experiments, it was established that about 94 strains of pathogenic flora were distinguished altogether in the test samples of the soil; the same tendency was inherent in the samples that were taken from nonirrigated soil. The use of raw wastewater for irrigation increases the development of resistibility of microorganisms, which can be observed even after a long period of time after the last irrigation [Palacios et al., 2017].

In this paper, we examined the effect of irrigation of treated water on the growth of Chinese cabbage and maize and on the soil features in Gaza Strip, Palestine. As a test object, Chinese cabbage and maize were chosen, which were planted in the sandy soil, in the winter and summer seasons, respectively. The samples of soil were taken from depths of $0.0-120.0 \mathrm{~cm}$ in all areas and the $\mathrm{pH}$, electrical conductivity (EC) and nutrient content in soil samples were subsequently determined. The plants were irrigated alternately with the treated wastewater and fresh water enriched with NPK. Biomass (complete fresh mass of plants) was used as an indicator of plant productivity. According to the results of the research, the biomass of Chinese cabbage and maize grown on sites irrigated with the treated wastewater was higher than with fresh water enriched with NPK. At the same time, the content of heavy metals in the leaves of plants during watering with fresh water and wastewater was almost the same and lower than the EPA standards, which indicates a high quality of plants. The analysis of the soil showed significant changes in soil features due to irrigation with wastewater [El-Nahhal et al., 2013].

The use of wastewater in the wine industry for irrigation of agricultural lands was widely applied in Australia. According to the results of the study, the long-term use of wastewater of this category has a significant effect on the composition of soil microbiota due to the presence of phospholipids in the wastewater with fatty acid, as well as on $\mathrm{pH}$, electrical conductivity and cation concentration. The use of raw wastewater has a significant impact on soil respiration and circulation of nitrogen and microorganisms. On the other hand, the use of the treated wastewater has not revealed any negative eco-toxicological consequences [Mosse, 2012; Zahida, Moore, Wrigley, 2011].

The use of the treated wastewater in agriculture was also tested in Brazil. The studies were conducted in Lins, São Paulo, to assess the use of the treated wastewater as an alternative source of water and nitrogen $(\mathrm{N})$ for the pastures sown with Bermuda Tifton 85 grass. The experiments lasted for two years, in the following variations: I) T1 (control) - irrigation with clean water and addition of mineral fertilizers $-520 \mathrm{~kg} / \mathrm{ha}-1$ year; II) T2-T5 - irrigation with treated wastewater $(31.9 \mathrm{mg} / \mathrm{kg})$ and addition of mineral fertilizers $-0 ; 171.6 ; 343.2$ and $520 \mathrm{~kg} / \mathrm{ha}-1$ year, respectively. The monthly characteristics of clean water and the treated wastewater were recorded, and the solid matter and crude protein content were determined once every two months. There was an increase in solid matter and crude protein during irrigation with the treated wastewater without the introduction of mineral fertilizers. Irrigation with the treated wastewater can help reduce the consumption of clean water and, at the same time, save $32-81.0 \%$ of mineral nitrogen fertilizers while maintaining stable yields with the required quality of grass [da Fonseca et al., 2007].

The re-use of the treated wastewater, in particular for irrigation, is an increasingly common practice that is encouraged by governments and official bodies around the world. When irrigating with wastewater, changes in the microbiological properties of the soil and/or the accumulation of chemical and biological contaminants in the soil are possible. The development of microbiota affects the fertility and structure of the soil, and the accumulation of chemical and biological contaminants can pose a serious threat to human health and the environment. In the work of Becerra-Cas- 
tro and Cristina, et al., the possible consequences of irrigation with the treated wastewater on the soil microbiota are analyzed. The results of the research led to the conclusion that the use of wastewater for irrigation purposes will create the conditions for the development of flora and fauna with minimal risk of chemical and biological soil contamination [Becerra-Castro et al., 2015].

The complex ecological assessment of the influence on the products of fractionation of liquid wastes of pig-breeding complexes on soil biota treated with phosophigus confirms the absence of their ecotoxic effect. The most favorable conditions for the development of microorganisms were created by introducing fractionation products with a $6.5 \mathrm{pH}$ into the soil. The number of microfungi with the introduction of solid phase was $9 \cdot 10^{8}$, liquid phase $-8.5 \cdot 10^{8}$, heterotrophs, respectively, $9.3 \cdot 10^{8}$ and $7 \cdot 10^{8}$; actinomycetes $9.1 \cdot 10^{8}$ and $7.3 \cdot 10^{8}$, phosphorus-reducing bacteria $-8.9 \cdot 10^{8}$ and $5.3 \cdot 10^{8}$, which indicates an improvement in the biological properties of the soil [Eliseeva, 2015; Domashenko, Vasilyev, 2015; Domashenko, Surzhko, 2009; Surzhko, Domashenko, 2009; Domashenko, Doroshko, 2010].

The specific properties of the wastewater from livestock enterprises, cultivated with defecate, containing toxic metals such as lead, titanium, zirconium, vanadium and niobium and chromium, in amounts that do not exceed $0.0005 \mathrm{wt}$. $\%$ [Perepelitsa, Ishchenko, Samchuk, 2014], led to the investigation of the effect of the appearing fractionation products on the basic forms of microbiota, characterizing the agroecological prosperity of soils,i.e. azotobacters, actinomycetes, microfungus, which are indicators of soil fertility.

Soil is a favorable medium for the development and accumulation of many species of bacteria, fungi, protozoa. The liquid phase of soils, i.e. soil solution, is the most active with respect to microorganisms. Most microorganisms develop and manifest their vital activity in the soil solution and in the solid areas of the soil. The presence of a large number of microorganisms in the soil is a conditional indicator of soil fertility. For a more complete and accurate representation of soil fertility, a study on the presence of certain physiological groups of microbes, i.e.ammonifying, nitrifying, cellulose-destroying, and others, as well as on the determination of their activity, is conducted [Mishustin, Emtsev, 1987; Mineev, 2001].

For this study, the treated wastewater from hog farms and cattle-breeding farms was taken with the following characteristics, presented in Table 1 [Domashenko, 2009].

Three series of experiments were carried out with samples of wastewater. Each series of experiments included 3 samples (4 times repetition), with an irrigation rate, $\mathrm{m}^{3} /$ ha: $250,350,450$.

Before processing, the number of microorganisms in $1 \mathrm{~g}$ of soil sample was, for pcs of colonies: Microfungus $-1.15 \cdot 10^{5}$; Azotobacter $7.1 \cdot 10^{4}$; actinomycetes $-130 \cdot 10^{3}$.

Tables 2 and 3 present the results of studies on the effect of irrigation with the treated wastewater from livestock farms on the main saproprotrophic groups of microorganisms in the soil.

On the basis of the obtained results, it was established that in the case of irrigation with treated wastewater, the total number of microorganisms, including bacteria that fix nitrogen, increases. Thus, at an irrigation rate of $250 \mathrm{~m}^{3} / \mathrm{ha}$, regardless of the category of wastewater, an increase in the number of colonies by an average of 1.5 times is observed; with a rate of $350 \mathrm{~m}^{3} / \mathrm{ha}$ - by an average of 2 times; with a rate of $450 \mathrm{~m}^{3} / \mathrm{ha}-$ by an average of 3.5-4 times.

Wastewater contributes to the accumulation of motile forms of nitrogen in the soil. The nitrifying ability of soil is an important indicator of

Table 1. Characteristics of wastewater from livestock farms after reactant treatment

\begin{tabular}{|l|c|c|}
\hline \multirow{2}{*}{ Indicator } & \multicolumn{2}{|c|}{ Wastewater } \\
\cline { 2 - 3 } & Hog farm & Cattle-breeding farms \\
\hline pH & 7.2 & 7.5 \\
\hline Moisture, \% & 99.5 & 96.3 \\
\hline Organic matter, \% & 68.2 & 59.5 \\
\hline Nitrogen, $\mathrm{mg} / \mathrm{dm}^{3}$ & & 625 \\
$\mathrm{NH}_{4}^{+}$ & 254 & 350 \\
$\mathrm{NO}_{2}^{-}$ & 151 & 0 \\
$\mathrm{NO}_{3}^{-}$ & 19 & 15 \\
\hline $\mathrm{P}_{2} \mathrm{O}_{5}, \mathrm{mg} / \mathrm{dm}^{3}$ & 12 & 487 \\
\hline $\mathrm{K}_{2} \mathrm{O}, \mathrm{mg} / \mathrm{dm}^{3}$ & 730 & 1100 \\
\hline
\end{tabular}


Table 2. The number of saprotrophic groups of microorganisms in the soil after irrigation with the wastewater from pig farms

\begin{tabular}{|c|c|c|c|}
\hline $\begin{array}{c}\text { Serial } \\
\text { number }\end{array}$ & $\begin{array}{l}\text { Irrigation } \\
\text { rate, } \mathrm{m}^{3} / \mathrm{ha}\end{array}$ & $\begin{array}{l}\text { Avarege number of } \\
\text { colony, pcs. }\end{array}$ & $\begin{array}{c}\text { Average } \\
\text { colony size, } \\
\mathrm{mm}\end{array}$ \\
\hline \multicolumn{4}{|c|}{ Actinomycetes } \\
\hline 1 & \multirow{3}{*}{250} & $106 \cdot 10^{3}$ & 0.9 \\
\hline 2 & & $180 \cdot 10^{3}$ & 0.4 \\
\hline 3 & & $189 \cdot 10^{3}$ & 0.7 \\
\hline 1 & \multirow{3}{*}{350} & $246 \cdot 10^{3}$ & 0.6 \\
\hline 2 & & $451 \cdot 10^{3}$ & 0.8 \\
\hline 3 & & $124 \cdot 10^{3}$ & 0.5 \\
\hline 1 & \multirow{3}{*}{450} & $253 \cdot 10^{3}$ & 1.1 \\
\hline 2 & & $236 \cdot 10^{3}$ & 0.7 \\
\hline 3 & & $197 \cdot 10^{3}$ & 0.8 \\
\hline \multicolumn{4}{|c|}{ Azotobacters } \\
\hline 1 & \multirow{3}{*}{250} & $25.5 \cdot 10^{4}$ & 0.3 \\
\hline 2 & & $22.3 \cdot 10^{4}$ & 0.5 \\
\hline 3 & & $15.3 \cdot 10^{4}$ & 1.6 \\
\hline 1 & \multirow{3}{*}{350} & $2.7 \cdot 10^{4}$ & 0.8 \\
\hline 2 & & $15.4 \cdot 10^{4}$ & 1.7 \\
\hline 3 & & $8.5 \cdot 10^{4}$ & 0.9 \\
\hline 1 & \multirow{3}{*}{450} & $28.6 \cdot 10^{4}$ & 1.3 \\
\hline 2 & & $26.3 \cdot 10^{4}$ & 1.3 \\
\hline 3 & & $17.3 \cdot 10^{4}$ & 1.0 \\
\hline \multicolumn{4}{|c|}{ Microfungus } \\
\hline 1 & \multirow{3}{*}{250} & $1.98 \cdot 10^{5}$ & 1.0 \\
\hline 2 & & $1.57 \cdot 10^{5}$ & 2.0 \\
\hline 3 & & $2.16 \cdot 10^{5}$ & 1.0 \\
\hline 1 & \multirow{3}{*}{350} & $1.82 \cdot 10^{5}$ & 1.8 \\
\hline 2 & & $2.27 \cdot 10^{5}$ & 1.5 \\
\hline 3 & & $3.82 \cdot 10^{5}$ & 3.0 \\
\hline 1 & \multirow{3}{*}{450} & $5.1 \cdot 10^{5}$ & 0.5 \\
\hline 2 & & $4.2 \cdot 10^{5}$ & 1.0 \\
\hline 3 & & $8.86 \cdot 10^{5}$ & 1.0 \\
\hline
\end{tabular}

the intensity of biological processes of the aerobic type and depends, first of all, on the nitrogen content in the soil (see Figure 1).

The analysis of Figure 1 shows that irrigation with the treated wastewater enhances the nitrifying ability of the soil. Thus, if the value on the control in the soil layer from $0 \mathrm{~cm}$ to $60 \mathrm{~cm}$ is $27.2 \mathrm{mg}$ of nitrate per $1 \mathrm{~kg}$ of arid soil, in the version with wastewater irrigation reaches $46.7 \mathrm{mg}$.

As the results of the research have shown, the use of waste from the sugar industry - defecate while processing wastewater from livestock farms does not have a negative agroecological effect on soils. The method of wastewater treatment of pigbreeding complexes and farms is recommended for irrigation amelioration, comprising the wastewater treated with a burnt defecate with a dose of
Table 3. The number of saprotrophic groups of microorganisms in the soil after the irrigation with the wastewater from cattle-breeding farms

\begin{tabular}{|c|c|c|c|}
\hline $\begin{array}{c}\text { Serial } \\
\text { number }\end{array}$ & $\begin{array}{l}\text { Irrigation } \\
\text { rate, } \mathrm{m}^{3} / \text { ha }\end{array}$ & $\begin{array}{l}\text { Avarege number of } \\
\text { colony, pcs. }\end{array}$ & $\begin{array}{c}\text { Average } \\
\text { colony size, } \\
\mathrm{mm}\end{array}$ \\
\hline \multicolumn{4}{|c|}{ Actinomycetes } \\
\hline 1 & \multirow{3}{*}{250} & $162 \cdot 10^{3}$ & 0.9 \\
\hline 2 & & $184 \cdot 10^{3}$ & 0.4 \\
\hline 3 & & $122 \cdot 10^{3}$ & 0.7 \\
\hline 1 & \multirow{3}{*}{350} & $140 \cdot 10^{3}$ & 0.6 \\
\hline 2 & & $192 \cdot 10^{3}$ & 0.8 \\
\hline 3 & & $185 \cdot 10^{3}$ & 0.5 \\
\hline 1 & \multirow{3}{*}{450} & $320 \cdot 10^{3}$ & 1.1 \\
\hline 2 & & $251 \cdot 10^{3}$ & 0.7 \\
\hline 3 & & $446 \cdot 10^{3}$ & 0.8 \\
\hline \multicolumn{4}{|c|}{ Azotobacters } \\
\hline 1 & \multirow{3}{*}{250} & $10.2 \cdot 10^{4}$ & 0.3 \\
\hline 2 & & $15.1 \cdot 10^{4}$ & 0.5 \\
\hline 3 & & $14.6 \cdot 10^{4}$ & 1.6 \\
\hline 1 & \multirow{3}{*}{350} & $12.1 \cdot 10^{4}$ & 0.8 \\
\hline 2 & & $18.2 \cdot 10^{4}$ & 1.7 \\
\hline 3 & & $13.5 \cdot 10^{4}$ & 0.9 \\
\hline 1 & \multirow{3}{*}{450} & $33.2 \cdot 10^{4}$ & 1.3 \\
\hline 2 & & $31.5 \cdot 10^{4}$ & 1.3 \\
\hline 3 & & $22.4 \cdot 10^{4}$ & 1.0 \\
\hline \multicolumn{4}{|c|}{ Microfungus } \\
\hline 1 & \multirow{3}{*}{250} & $2.12 \cdot 10^{5}$ & 1.0 \\
\hline 2 & & $1.61 \cdot 10^{5}$ & 2.0 \\
\hline 3 & & $2.70 \cdot 10^{5}$ & 1.0 \\
\hline 1 & \multirow{3}{*}{350} & $1.91 \cdot 10^{5}$ & 1.8 \\
\hline 2 & & $2.39 \cdot 10^{5}$ & 1.5 \\
\hline 3 & & $5.84 \cdot 10^{5}$ & 3.0 \\
\hline 1 & \multirow{3}{*}{450} & $2.21 \cdot 10^{5}$ & 0.5 \\
\hline 2 & & $4.24 \cdot 10^{5}$ & 1.0 \\
\hline 3 & & $3.42 \cdot 10^{5}$ & 1.0 \\
\hline
\end{tabular}

$50-200 \mathrm{mg} / \mathrm{dm}^{3}$, and the $\mathrm{pH}$ varying between 7.5 and 8.5. After settling-out of the resulting mixture in a settler, it is divided into a transparent liquid fraction and a sediment - an organomineral fertilizer. Afterwards, the liquid phase is fed to irrigation of agricultural land, and its excess is discharged into waterways and reservoirs. The sediment is fed to the vortex layer equipment with mobile ferromagnetic particles or thermolized, where their complete disinfection takes place.

According to the proposed method, the wastewater of pig-breeding complexes, with an initial suspended matter content of $30 \mathrm{mg} / \mathrm{l}$, is treated with a burnt defecate at a dose of $200 \mathrm{mg} / \mathrm{dm}^{3}$ (pH 8.5). Subsequently, the treating effect on suspended and organic matters in the liquid phase reaches $99 \%$. 


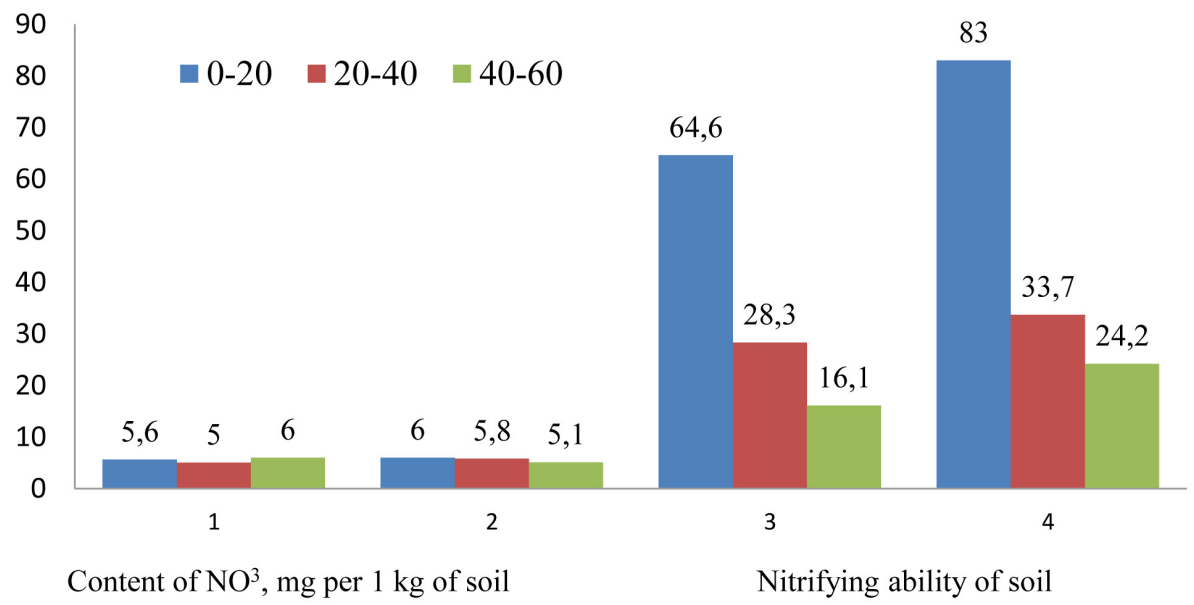

Fig. 1. Effect of wastewater on the nitrifying ability of the soil: 1,3 - control without irrigation; 2, 4 - wastewater irrigation

The results of the studies on the processing of wastewater of pig-breeding complexes and farms by a burnt defecate for the known method are presented in Table 4.

The results of the studies of the physicochemical indicators of wastewater after treatment with a burnt defecate allowed us to recommend a liquid fraction for irrigation, and a solid one, after preliminary substantiation, as an organomineral fertilizer.

\section{CONCLUSIONS}

The secondary use of wastewater from agroenterprises that had undergone preliminary treatment can contribute to solving the crisis situations existing in the regions with insufficient water resources. Throughout the world, there are serious problems with water supply, provoked by a decrease in the supply of water resources, and, therefore, the issue with a deficit of irrigation water is even more acute.

The microflora of the soil plays an important role in strengthening or weakening the biological activity of the soil. When irrigated with the treated wastewater, the composition of soil microflora changes significantly. Thus, with an irrigation norm of $250 \mathrm{~m}^{3} / \mathrm{ha}$, regardless of the category of wastewater, an increase in the number of colonies by an average of 1.5 times is observed; with a rate of $350 \mathrm{~m}^{3} / \mathrm{ha}-2$-fold; with a rate of $450 \mathrm{~m}^{3} / \mathrm{ha}$ $-3.5-4$-fold.

The process of nitrification is the indicator of biogenic and soil self-cleaning, while irrigation with the treated wastewater intensifies the nitrifying ability of the soil. Thus, if the value on the control in the soil layer from $0 \mathrm{~cm}$ to $60 \mathrm{~cm}$ is 27.2

Table 4. The results of studies on the processing of wastewater of pig-breeding complexes and farms by a burnt defecate

\begin{tabular}{|c|c|c|c|c|c|c|c|c|}
\hline \multirow[b]{2}{*}{ Indicators } & \multicolumn{4}{|c|}{ Liquid phase } & \multicolumn{4}{|c|}{ Solid phase } \\
\hline & \multirow{2}{*}{$\begin{array}{c}\begin{array}{c}\text { before } \\
\text { processing }\end{array} \\
6.4\end{array}$} & \multicolumn{3}{|c|}{ after processing } & \multirow{2}{*}{$\begin{array}{c}\begin{array}{c}\text { before } \\
\text { processing }\end{array} \\
6.7\end{array}$} & \multicolumn{3}{|c|}{ after processing } \\
\hline $\mathrm{pH}$ & & 7.5 & 8.0 & 8.5 & & 7.8 & 8.1 & 8.5 \\
\hline Moisture, $\%$ & 99.7 & 100.00 & 100.00 & 100.00 & 98.0 & 91.2 & 91.2 & 91.2 \\
\hline $\begin{array}{l}\text { Nitrogen, } \mathrm{mg} / \mathrm{dm}^{3} \\
\text { total } \\
\mathrm{NH}_{4}{ }^{+} \\
\mathrm{NO}_{2}^{-} \\
\mathrm{NO}_{3}^{-}\end{array}$ & $\begin{array}{c}600 \\
550 \\
0 \\
30 \\
\end{array}$ & $\begin{array}{c}300 \\
200 \\
20 \\
20 \\
\end{array}$ & $\begin{array}{c}250 \\
155 \\
18 \\
17.5\end{array}$ & $\begin{array}{c}220 \\
175 \\
15 \\
14.6\end{array}$ & $\begin{array}{c}300 \\
100 \\
0 \\
38 \\
\end{array}$ & $\begin{array}{c}400 \\
300 \\
20 \\
55\end{array}$ & $\begin{array}{c}450 \\
350 \\
25 \\
55\end{array}$ & $\begin{array}{c}460 \\
380 \\
22 \\
55\end{array}$ \\
\hline $\mathrm{P}_{2} \mathrm{O}_{5}, \mathrm{mg} / \mathrm{dm}^{3}$ & 700 & 100 & 80 & 75 & 200 & 800 & 830 & 860 \\
\hline $\mathrm{COD}, \mathrm{mg} / \mathrm{dm}^{3}$ & 15050 & 10040 & 8500 & 8000 & 17600 & 11900 & 12900 & 13500 \\
\hline $\mathrm{K}_{2} \mathrm{O}, \mathrm{mg} / \mathrm{dm}^{3}$ & 830 & 300 & 280 & 250 & 450 & 980 & 987 & 1020 \\
\hline Total bacterial count in $1 \mathrm{ml}$ & $4 \cdot 10^{6}$ & None & None & None & $1.5 \cdot 10^{7}$ & None & None & None \\
\hline $\begin{array}{l}\text { The content of helmint eggs, } \\
\mathrm{pcs} / \mathrm{dm}^{3}\end{array}$ & 20 & None & None & None & $4 \cdot 10^{4}$ & None & None & None \\
\hline
\end{tabular}


$\mathrm{mg}$ of nitrate per $1 \mathrm{~kg}$ of arid soil, in the version with wastewater irrigation it reaches $46.7 \mathrm{mg}$.

The results of the studies allowed us to recommend the method of wastewater treatment of pig-breeding complexes and farms for irrigation of agricultural land, comprising the wastewater treated with a burnt defecate with a dose of 50-200 $\mathrm{mg} / \mathrm{dm}^{3}$, and the $\mathrm{pH}$ varying between 7.5 and 8.5.

\section{REFERENCES}

1. Becerra-Castro, C., Lopes, A.R., Vaz-Moreira, I., Silva, E.F., Manaia, C.M., Nunes, O.C. 2015. Wastewater reuse in irrigation: A microbiological perspective on implications in soil fertility and human and environmental health. Environment International, 75, 117-135. https://doi.org/10.1016/j. envint.2014.11.001

2. da Fonseca A. F., Melfi, A.J., Monteiro, F.A., Montes, S.R., de Almeida, V.V., Herpin, U. 2007. Treated sewage effluent as a source of water and nitrogen for Tifton 85 bermudagrass. Agricultural Water Management, 87(3), 328-336. https://doi. org/10.1016/j.agwat.2006.08.004

3. Domashenko, Yu. E., Doroshko, V.N. 2010. Method of preparing livestock wastewater for agricultural use: pat. 2379236, Russian Federation, IPC C 02 F 1/58 /- No. 2009114816/05; appl. June 6, 2008; publ. January 20, 2010, Bul. No. 2.

4. Domashenko, Yu. E., Surzhko, O. A. 2009. Method of preparing liquid wastes of cattle-breeding farms for the cultivation of cattle for agricultural use: patent 2350571, Russian Federation, IPC C 02 F11/14, C 02 F1/52. No. 2007127042/15; appl. July 16, 2007; publ. March 27, 2009, Bul. No. 9.

5. Domashenko, Yu.E. 2009. Reduction of negative influence of water wash-out products from pigbreeding farms on natural ecosystems. Ecology and Industry of Russia, 10, 44-45.

6. Domashenko, Yu.E., Vasilyev, S.M. 2015. Technology for the preparation of livestock wastewater for irrigation of agricultural crops. Polythematic online scientific journal of Kuban State Agrarian University, 106(02), 568-579.

7. Eliseeva, D. V. 2015. Protection of the environment from the negative impact of economic activity. Novosibirsk, SibAK.

8. El-Nahhal, Y., Tubail, K., Safi, M., Safi, J. 2013. Effect of Treated Waste Water Irrigation on Plant Growth and Soil Properties in Gaza Strip, Palestine. American Journal of Plant Sciences, 4(9), 1736-1743. doi: 10.4236/ajps.2013.49213.

9. Feigin, A., Ravina, I., Shalhevet, J. 1991. Irrigation with treated sewage effluent. SpringerVerlag. Berlin.
10. Glotov, I.I. 1987. Use of secondary resources in the agroindustrial complex. Moscow, Rosselkhozizdat.

11. Gostishchev, P. 1994. Technique and technology of irrigation of wastewater with regard to environmental protection. Doctoral dissertation (in the form of a scientific report). Moscow, VNIIGiM.

12. Khaskhoussy, K., Kahlaoui, B., Messoudi Nefzi, B., Jozdan, O., Dakheel, A., Hachicha, M. 2015. Effect of Treated Wastewater Irrigation on Heavy Metals Distribution in a Tunisian Soil. Engineering, Technology \& Applied Science Research, 5(3), 805-810. http://doi.org/10.5281/zenodo.18803.

13. Mineev, V.G. 2001. Practical course on agrochemistry. Moscow: Moscow State University.

14. Mishustin, E.M., Emtsev, V.T. 1987. Microbiology. Moscow, Agropromizdat.

15. Mosse, K.P.M., Patti, R. A.F., Smernik, J., Christen, E.W., Cavagnaro, T.R. 2012. Physicochemical and microbiological effects of long-and short-term winery wastewater application to soils. Journal of Hazardous Materials, 201, 219-228.

16. Palacios, O. A., Contreras, C.A., Munoz-Castellanos, L. N., Gonzalez-Rangel, M. O., Rubio-Arias, H., Palacios-Espinosa, A., Nevarez-Moorillon, G.V. 2017. Monitoring of indicator and multidrug resistant bacteria in agricultural soils under different irrigation patterns. Agricultural Water Management, 184, 19-27.

17. Perepelitsa, A.P., Ishchenko, V.N., Samchuk, A.I. 2014. Defecation of sugar production: processing areas. Sugar, 2, 41-42.

18. Qian, Y. L., Mecham, B. 2005. Long-term effects of recycled wastewater irrigation on soil chemical properties on golf course fairways. Agronomy Journal, 97(3), 717-721.

19. Shchedrin, V.N., Vasiliev, S.M. 2011. Theory and practice of alternative types of irrigation of chernozems in the south of the European territory of Russia: monograph. Novocherkassk, Lik.

20. State report "On the state and protection of the environment of the Russian Federation in 2015". 2016. Moscow, Ministry of Natural Resources and Environment of the Russian Federation; NIA-Nature.

21. Surzhko, O.A., Domashenko, Yu. E. 2009. Method of preparing liquid wastes of pig farms for agricultural use: pat. 2424985, Russian Federation, IPC C 02 F 9/12, C 02 F 1/52 / - No. 2008122872/15; appl. April 13, 2009; publ. October 20, 2010, Bul. No. 29.

22. Tepper, E.Z., Shilnikova, V.K., Pereverzeva, G.I. 1979. Practical course on microbiology. Moscow, Kolos.

23. Zahida, M., Moore, G.A., Wrigley, R.J. 2011. Soil salinity and sodicity effects of wastewater irrigation in South East Australia. Agricultural Water Management, 99(1), 33-41. 